\title{
Programa da União pela Liberdade e pelos Direitos do Povo (1972)
}

União pela Liberdade e pelos Direitos do Povo (ULDP)

A União do Povo do interior deve fazer-se partindo de suas reivindicações mais sentidas e mais imediatas. Que deseja o homem do interior? Quais são os problemas que mais o afetam? Ele quer:

1. Terra para trabalhar e título de propriedade de sua posse.

2. Combate à grilagem, com castigo severo a todos que grilarem terras.

3. Preços mínimos compensatórios para os produtos da região, preços que não se distanciem muito dos que estão em vigência nos grandes mercados de consumo. Criação de Distribuidoras do Estado, que adquirem por preços fixados todos os produtos que Ihe sejam oferecidos e, ao mesmo tempo, vendam com uma pequena margem de lucro, e também a prazo, adubos, ferramentas, venenos, sementes, máquinas de fabricar farinha, lonas para a colheita de arroz, moinhos, etc.

4. Facilidades para o deslocamento da produção através de diferentes meios de transportes, e financiamento ao lavrador para a compra de animais.

5. Proteção à mão-de-obra dos que trabalham nos castanhais, na extração da madeira ou nas grandes fazendas. O casta-

1 Extraído de MOURA, Clóvis (org.). Diário da guerrilha do Araguaia. São Paulo: AlfaÔmega, 1979, p. 75-80. 
nheiro deve receber por hectolitro da castanha cortada um preço que seja, pelo menos, um terço do fixado pelo governo para a cidade de Marabá. $O$ hectolitro deve ser de 6 latas de parafina, sem cálculo e sem arredondar as latas. O preço das mercadorias vendidas nos armazéns não pode exceder em muito o preço corrente nas cidades e povoados próximos. O pagamento ao castanheiro deve ser realizado no local de trabalho. Os trabalhadores da exploração da madeira ou das grandes fazendas devem receber seus salários em dinheiro no final de cada mês, não sendo permitido o pagamento de salários em espécie ou bagulho.

6. Assegurar aos 'garimpeiros' o direito de trabalhar livremente e a regulamentação de sua atividade, impedindo que seja explorado na venda dos bens obtidos em seu trabalho.

7. Liberdade de caça e pesca para sua alimentação, permitindo-se a venda das peles dos animais por eles mortos para o seu consumo. A matança generalizada de caça com o único objetivo de comercializar as peles deve ser proibida.

8. Liberdade para coletar, quebrar e vender o babaçu.

9. Redução dos impostos que recaem sobre o trabalho da terra e sobre o pequeno comércio. Os pequenos e médios lavradores não devem pagar nenhum imposto ou taxa ao INCRA. Liquidação do sistema de multas dos serviços de impostos e da cobrança de impostos com o auxílio da polícia.

10. Direito de todo lavrador ou trabalhador da selva possuir sua arma de caça e de defesa pessoal.

11. Assistência médica por meio de postos instalados em zonas e distritos e também de postos ambulantes montados sobre embarcações e caminhões. Serviço médico gratuito, para as doenças endêmicas, e pago a preços módicos, para as doenças evitáveis, como a sífilis. Combate sistemático e eficaz à malária e à verminose. 
12. Criação de escolas nos povoados, nas margens dos grandes rios, nas proximidades de vários plantações, com doação de material escolar. Construção de internatos para crianças que vivem longe das escolas, com custos de 8 a 10 meses de duração.

13. Fim das arbitrariedades da polícia contra o povo. A polícia não pode cobrar suas diligências, autorização para festas, as prisões, não pode prender ninguém sem motivo plenamente justificado. Não tem direito a bater nos presos, nem tirar armas, animais, instrumentos de trabalho ou objetos de utilização do homem do interior. Os policiais estão obrigados a manter uma atitude de respeito com o lavrador e sua família, como também em relação às mulheres.

14. Casamento civil e registro de nascimento gratuitos.

15. Proteção à mulher. Em caso de separação do marido ou companheiro a mulher tem direito a uma parte da produção e dos bens domésticos, de acordo com o trabalho desenvolvido, direta ou indiretamente, para a obtenção ou produção desses bens. Ajuda à maternidade. Cursos práticos para formar novas parteiras ou melhorar os conhecimentos técnicos das que já trabalham na região, com o objetivo de garantir uma melhor assistência às mulheres grávidas.

16. Trabalho, instrução e educação física para a juventude. Estímulo ao desenvolvimento do esporte, com a construção de campos de futebol e de basquete, pistas de atletismo e outras iniciativas. Ajuda à criação de clubes, centros recreativos e culturais e à construção de suas sedes.

17. Respeito a todos os religiosos, não sendo permitida a perseguição a qualquer pessoa por motivos de prática religiosa, inclusive de quem professa a pagelância, o tererecô (religiões da região), o espiritismo, sempre que esta prática não cause danos a indivíduo. 
18. Liberdade para reunir-se, discutir seus problemas, criticar as autoridades, exigir seus direitos, organizar suas associações e eleger, sem pressão de nenhum tipo, seus representantes.

19. Criação de Comitês Populares, eleitos diretamente pelo povo, para administrar os distritos e povoados, orientar as iniciativas que têm relação com a coletividade e resolver as desavenças surgidas entre os habitantes. Os Comitês estabelecem, de comum acordo com o povo, as normas de proteção à plantação, contra a invasão de gado, porcos e outros animais, assim como orientam a maneira de criá-los sem causar prejuízo aos interesses coletivos.

20. Eleição livre do prefeito de um Conselho Administrativo nos municípios, assim como de Comitês populares nos bairros das cidades.

21. Emprego de boa parte dos impostos arrecadados nos municípios para o desenvolvimento das cidades e povoados. O Governo Federal e o Governo Estadual de cada Estado devem ajudar aos municípios na construção de estradas, pavimentação de ruas, instalação de luz e água, manutenção de escolas e execução de serviços médicos.

22. Elaboração de planos de urbanização e desenvolvimento em todas as cidades. Facilidades para a construção de casas, estímulo à criação de bibliotecas e radioemissoras locais, sem que seja necessário nenhuma permissão das autoridades para seu funcionamento.

23. As terras do Estado abandonadas e localizadas nas proximidades dos povoados e pequenas cidades devem ser distribuídas anualmente entre os habitantes, para que sejam cultivadas por um ano.

24. Aproveitamento racional das grandes áreas não cultivadas em torno das cidades e povoados para a criação de granjas e plantações rentáveis, com o objetivo de garantir trabalho e meio de vida à população da região. 
25. Defesa da terra dos índios, respeito a seus hábitos e costumes e ajuda do Governo aos indígenas.

26. Obrigação de reflorestamento e aproveitamento total das árvores derrubadas na exploração de madeira em larga escala. O benefício da madeira deve ser feito na região para incentivar seu progresso. A madeira existente em cada área determinada de terra pertence ao posseiro.

27. Respeito à propriedade privada que não ocasione prejuízo à coletividade. Apoio às iniciativas privadas de caráter progressista, à pequena e média indústria e ao artesanato.

A UNIÃO PELA LIBERDADE E PELOS DIREITOS DO POVO, surgida para unir as amplas massas, crê que esses 27 pontos sintetizam as reivindicações mais sentidas e imediatas do homem desta região. Incluem tudo que ele deseja e tem direito. Representam, contudo, o mínimo exigido por ele nas condições atuais. Por isso a ULDP considera que este é um programa em defesa dos pobres e pelo progresso do interior. Em torno dele se unirá o povo sofrido: os lavradores, os castanheiros, os vaqueiros, os garimpeiros, os peões, os barqueiros, os que trabalham na madeira e na quebra de babaçu, os pequenos e médios comerciantes, enfim, todos os que querem o progresso da região e a facilidade de seus habitantes.

É hora da decisão, de acabar para sempre com o abandono em que vive o interior e de pôr fim aos incontáveis sofrimentos de milhões de brasileiros abandonados, humilhados e explorados.

A Revolução abrirá o caminho para uma nova vida.

Até hoje, o povo foi tratado como escravo. Chegou o momento de levantar-se para varrer os inimigos da liberdade, da independência e do progresso do Brasil. 